\title{
MODEL KURVA LORENZ PADA PENGELUARAN RUMAH TANGGA PERTANIAN DI PROVINSI PAPUA
}

\author{
Muhammad Fajar ${ }^{1}$ \\ ${ }^{1}$ Badan Pusat Statistik Provinsi Banten \\ mfajar@bps.go.id ${ }^{1}$
}

\begin{abstract}
Based on previous research, it shows that the distribution of agricultural household expenditure in Papua Province is the distribution of Generalized Beta Type 2 (GB2), but according to the author, if the Lorenz curve model is derived from the Generalized Beta Type 2 distribution, it has a complex shape and is not simple and implicit. Therefore, this paper aims to model the Lorenz curve for agricultural household expenditure in Papua Province using the Rohde version of the Lorenz curve model, which is a one-parameter model. There are three formulas to estimate parameters in Lorenz curve modeling, namely, arithmetic mean, median and least square. In this paper, the authors add the harmonic and trimean mean formulas to obtain the estimated parameter values on the Lorenz curve. The results of this study conclude that the Rohde version of Lorenz model can be applied and the estimation in the model results that $\widehat{\boldsymbol{\beta}}$ derived from the median has a minimum mean squared error, so the resulting Gini ratio has high accuracy and precision and is in accordance with the distribution of data.
\end{abstract}

Keywords: Lorenz Curve, expenditure, Rohde, Papua

\begin{abstract}
Abstrak
Berdasarkan penelitian sebelummya menunjukkan bahwa distribusi pengeluaran rumah tangga pertanian Provinsi Papua adalah distribusi Generalized Beta Type 2 (GB2), namun menurut penulis jika model kurva Lorenz diturunkan dari distribusi Generalized Beta Type 2 memiliki bentuk yang rumit dan tidak sederhana serta implisit. Oleh karena itu, tujuan paper ini adalah untuk memodelkan kurva Lorenz pengeluaran rumah tangga pertanian Provinsi Papua dengan menggunakan model kurva Lorenz versi Rohde, yang merupakan model dengan satu parameter. Terdapat tiga rumusan untuk mengestimasi parameter dalam pemodelan kurva Lorenz, yaitu rata-rata aritmatik, median dan least square. Dalam paper ini, penulis menambahkan rumusan rata-rata harmonis dan trimean untuk mendapatkan nilai estimasi parameter pada kurva Lorenz. Hasil penelitian ini menyimpulkan bahwa model Lorenz versi Rohde dapat diterapkan dan estimasi pada model tersebut menghasilkan bahwa $\widehat{\boldsymbol{\beta}}$ yang diturunkan dari median memiliki mean squared error minimum, sehingga gini ratio yang dihasilkan memiliki akurasi dan presisi yang tinggi serta sesuai dengan sebaran data.
\end{abstract}

Kata kunci: kurva Lorenz, Pengeluaran, Rohde, Papua,. 
Jurnal Lebesgue : Jurnal Ilmiah Pendidikan Matematika, Matematika dan Statistika

Muhammad Fajar

Volume 1, No. 3, Desember 2020 hal.153-158

DOI Artikel : 10.46306/lb.v1i3.31

\section{PENDAHULUAN}

Kurva Lorenz adalah gambaran visual yang dapat mencerminkan ketidekamerataan distribusi pendapatan. Kurva tersebut dikonstruksi oleh Lorenz (1905) untuk merepresentasikan ketidakmerataan distribusi kekayaan. Selanjutnya, dalam melakukan pemodelan kurva Lorenz dapat ditempuh tiga cara, yaitu: (1) kurva Lorenz dapat dituangkan dalam bentuk model parametrik yang tidak diturunkan dari distribusi teoretis, melainkan langsung melakukan fitting model (Kakwani dan Podder, 1976; Rasche et al., 1980; Gupta, 1984; Ortega, et al., 1991; Sarabia et al., 1999; Chotikapanich et al., 2007; Rohde, 2009;), (2) kurva Lorenz dikonstruksikan dari data kelompok dengan menggunakan teknik interpolasi (Gastwirth dan Glauberman, 1976), dan (3) kurva Lorenz diturunkan dari suatu distribusi teoretis tertentu (Gastwirth, 1971).

Fajar (2017) menunjukkan bahwa distribusi pengeluaran rumah tangga petani Provinsi Papua adalah distribusi Generalized Beta Type 2 (GB2), namun menurut penulis jika model kurva Lorenz diturunkan dari distribusi Generalized Beta Type 2 memiliki bentuk yang rumit dan tidak sederhana serta implisit. Oleh karena itu, tujuan paper ini adalah untuk memodelkan kurva Lorenz pengeluaran rumah tangga pertanian Provinsi Papua dengan model sederhana yang memiliki satu parameter. Penulis mengaplikasikan model kurva Lorenz versi Rohde (Rohde, 2009) karena model ini lebih fit dibandingkan model kurva Lorenz dengan satu parameter lainnya, seperti Chotikapanich (1993), Pareto, dan Kakwani-Podder (1976). Namun, dalam penentuan estimasi parameter dalam model Rohde selain menggunakan parameter yang ditentukan oleh rata-rata aritmatik, median dan least square (Sarabia et al., 2010), penulis juga menentukan parameter berdasarkan rata-rata harmonis dan trimean, dimana kedua ukuran pemusatan tersebut adalah hasil kombinasi dari ukuran pemusatan lainnya dan robust terhadap fluktuasi observasi yang ekstrem (Tukey, 1977; Weisberg, 1992; Xia et al., 1999). Implikasinya, pemilihan estimasi parameter didasarkan pada mean squared error (MSE) minimum yang dihasilkan dari estimasi parameter melalui metode rata-rata aritmatik, median, least square, rata-rata harmonis dan trimean.

\section{METODE PENELITIAN}

Data yang digunakan dalam penelitian ini adalah data total pengeluaran rumah tangga pertanian selama sebulan bersumber dari Survei Sosial Ekonomi Nasional (SUSENAS) yang dilaksanakan BPS. Proses filter provinsi dataset SUSENAS tahun 2016 hanya untuk Provinsi Papua dan rumah tangga pertanian1. Kerangka sampel induk atau sampling frame induk kegiatan Susenas, Sakernas, dan SUPAS 2015 adalah sekitar 180.000 blok sensus (25 persen populasi) yang ditarik secara PPS (Probability Proportional to Size) dengan size rumah tangga SP2010 dari master frame blok sensus. Selanjutnya untuk kegiatan Susenas didefinisikan sebagai berikut (BPS, 2016):

1. Kerangka sampel tahap pertama adalah daftar blok sensus biasa SP2010. 
Jurnal Lebesgue : Jurnal Ilmiah Pendidikan Matematika, Matematika dan Statistika

Muhammad Fajar

Volume 1, No. 3, Desember 2020 hal.153-158

DOI Artikel : 10.46306/lb.v1i3.31

2. Kerangka sampel tahap kedua adalah daftar 25 persen blok sensus SP2010 yang sudah ada kode stratanya. 25 persen blok sensus ini disebut sampling frame induk.

3. Kerangka sampel tahap ketiga adalah daftar rumah tangga hasil pemutakhiran di setiap blok sensus terpilih.

Tahun 2016, pengumpulan data SUSENAS dilaksanakan pada Bulan Maret 2016. Jumlah sampel total sampel SUSENAS sebanyak 300000 rumah tangga (BPS, 2016). Pengumpulan data dari rumah tangga terpilih dilakukan melalui wawancara tatap muka antara pencacah dengan responden. Untuk pertanyaan-pertanyaan dalam kuesioner yang ditujukan kepada individu diusahakan agar individu yang bersangkutan yang menjadi responden. Keterangan tentang rumah tangga dikumpulkan melalui wawancara dengan kepala rumah tangga, suami/istri kepala rumah tangga atau anggota rumah tangga lain yang mengetahui karakteristik yang ditanyakan.

\section{Kurva Lorenz}

Sebuah kurva Lorenz dapat didefinisikan sebagai:

$$
q=L(p)
$$

dengan: $q$ adalah kumulatif proprorsi pendapatan/ pengeluaran dari populasi subgroup $p$, dan $p$ adalah kumulatif proporsi populasi penduduk yang memiliki pendapatan/ pengeluaran pada level tertentu, dimana $0 \leq p \leq 1$. Kurva Lorenz harus memiliki karakteristik sebagai berikut (Rasche et al., 1980; Sarabia et al., 2010):

$$
\frac{d L}{d p}>0, \quad \frac{d^{2} L}{d p^{2}}>0, \quad L(p)=0, \quad L(0)=0, \quad L(1)=1
$$

\section{Kurva Lorenz Versi Rohde}

Rohde (2009) mengusulkan model kurva Lorenz sebagai berikut:

$$
L_{R}(p ; \beta)=\frac{(\beta-1) p}{\beta-p}, \beta>1,0 \leq p \leq 1
$$

Berdasarkan persamaan (1) dapat diturunkan formula koefisien Gini sebagai berikut:

$$
G=2 \beta\left[(\beta-1) \ln \left(\frac{\beta-1}{\beta}\right)+1\right]-1
$$

Untuk mengestimasi parameter $\beta$ pada persamaan (1), penulis menggunakan metode yang diusulkan Castillo et al. (1998) berdasarkan titik $\left(p_{i}, q_{i}\right), i=1, \ldots, n$ pada kurva Lorenz empiris:

$$
\hat{\beta}_{i}=\frac{p_{i}\left(1-q_{i}\right)}{p_{i}-q_{i}}
$$

Terjadi bahwa $p_{i}=q_{i}=0$ yang mengakibatkan nilai $\hat{\beta}_{i}$ tidak didefinisikan sehingga harus dibuang yang berimplikasi banyaknya $\hat{\beta}_{i}$ berkurang satu $(n-1)$ pada persamaan (4), (5), (7), dan (8), kecuali (6).

Estimasi $\beta$ pada persamaan (1) adalah: 


$$
\begin{aligned}
\hat{\beta}_{M} & =\frac{1}{n-1} \sum_{i=1}^{n-1} \hat{\beta}_{i} \\
\hat{\beta}_{M e d} & =\operatorname{Median}\left(\hat{\beta}_{1}, \hat{\beta}_{2}, \ldots, \hat{\beta}_{n-1}\right) \\
\hat{\beta}_{L S} & =\frac{\sum_{i=1}^{n-1} p_{i}\left(1-q_{i}\right)\left(p_{i}-q_{i}\right)}{\sum_{i=1}^{n-1}\left(p_{i}-q_{i}\right)^{2}}
\end{aligned}
$$

Namun, penulis juga mengajukan estimasi $\beta$ berdasarkan rata-rata harmonis (7), dan trimean (8), yaitu:

$$
\begin{aligned}
& \hat{\beta}_{H M}=\frac{n-1}{\sum_{i=1}^{n-1} \frac{1}{\hat{\beta}_{i}}} \\
& \hat{\beta}_{T M}=\frac{Q_{1}\left(\hat{\beta}_{1}, \hat{\beta}_{2}, \ldots, \hat{\beta}_{n-1}\right)+2 Q_{2}\left(\hat{\beta}_{1}, \hat{\beta}_{2}, \ldots, \hat{\beta}_{n-1}\right)+Q_{3}\left(\hat{\beta}_{1}, \hat{\beta}_{2}, \ldots, \hat{\beta}_{n-1}\right)}{4}
\end{aligned}
$$

dengan $Q_{1}(),. Q_{2}($.$) , dan Q_{3}($.$) masing-masing adalah kuartil pertama, kuartil kedua dan kuartil ketiga$ dari sebuah data.

Prosedur pengolahan ini adalah sebagai berikut:

1. Filter dataset SUSENAS pada variabel pengeluaran total (makanan dan bukan makanan), hanya untuk rumah tangga pertanian.

2. Lakukan ekstrak pada hasil filter langkah (1), sehingga diperoleh dataset hasil filter yang disebut dataset rumah tangga tani.

3. Pada dataset rumah tangga tani, dilakukan proporsi terhadap count rumah tangga tani dan proporsi terhadap pengeluaran total.

4. Kemudian, dilakukan penghitungan melalui persamaan (3).

5. Hasil langkah (4), memberikan barisan nilai $\hat{\beta}_{i}$, kemudian lakukan penghitungan berdasarkan persamaan (4), (5), (6), (7), dan (8).

6. Kemudian dari berbagai $\hat{\beta}$ yang diturunkan dari (4), (5), (6), (7), dan (8) sehingga menghasilkan $\hat{q}$ (melalui persamaan (1)) yang berbeda sesuai dengan jenis $\hat{\beta}$.

7. Lalu hitung mean squared error

$$
\text { MSE }=\sum_{i=1}^{n} \frac{\left(q_{i}-\hat{q}_{i}\right)^{2}}{n}
$$

8. Kemudian, pilihlah nilai $\hat{\beta}$ yang menghasilkan MSE minimum. Lalu, masukkan ke dalam persamaan (1), dengan demikian diperoleh model kurva Lorenz versi Rohde dengan hasil estimasi $\hat{\beta}$.

\section{HASIL DAN PEMBAHASAN}

Untuk mengetahui goodness of fit dari berbagai $\hat{\beta}$ yang diturunkan dari (4), (5), (6), (7), dan (8) sehingga menghasilkan $\hat{q}$, penulis menggunakan mean squared error (MSE), berikut tabel MSE dari berbagai estimasi $\hat{\beta}$ : 
Tabel 1. MSE dari Berbagai $\hat{\beta}$

\begin{tabular}{|c|c|}
\hline Estimasi $\beta$ & MSE \\
\hline$\hat{\beta}_{M}=1.453$ & $3.48 \times 10^{-5}$ \\
\hline$\hat{\beta}_{M e d}=1.485$ & $\mathbf{1 . 6 2} \times \mathbf{1 0}^{-\mathbf{5}}$ \\
\hline$\hat{\beta}_{L S}=1.581$ & $2.37 \times 10^{-5}$ \\
\hline$\hat{\beta}_{H M}=1.446$ & $4.14 \times 10^{-5}$ \\
\hline$\hat{\beta}_{T M}=1.475$ & $2.09 \times 10^{-5}$ \\
\hline
\end{tabular}

Berdasarkan kriteria MSE yang disajikan dalam tabel 3.1, dapat diketahui bahwa $\hat{\beta}$ yang diturunkan dari persamaan (5) memiliki MSE minimum. Ini disebabkan karena karaketristik median memiliki tingkat robust lebih tinggi dibandingkan ukuran lainnya dan distribusi sampling dari median stabil (Basu dan Dasgupta, 1997; Rousseeuw dan Bassett, 1990) sehingga dalam kasus pemodelan kurva Lorenz pengeluaran rumah tangga pertanian Provinsi Papua berdasarkan persamaan (1) adalah sebagai berikut:

$$
L_{R}\left(p_{i}\right)=\frac{0.485 p_{i}}{1.485-p_{i}}
$$

Persamaan (9) ini memiliki bentuk lebih sederhana dan gini rasio dapat dihitung secara langsung, cepat dan mudah dibandingkan cara tebulasi data konvensional. Dari persamaan (9) diperoleh nilai rasio gini sebesar 0.385, yang berarti tingkat ketimpangan pendapatan pada rumah tangga pertanian di Provinsi Papua dalam kategori rendah. Implikasi selanjutnya, karena persamaan (9) didasarkan kriteria MSE minimum sehingga gini ratio yang dihasilkan lebih akurat dan presisi serta sesuai sebaran data.

\section{KESIMPULAN}

Berdasarkan hasil pembahasan dapat disimpulkan bahwa model kurva Lorenz menggunakan pendekatan Rohde dapat diterapkan pada data pengeluaran rumah tangga pertanian dengan estimasi $\hat{\beta}$ yang diturunkan berdasarkan median dari $\hat{\beta}_{1}, \hat{\beta}_{2}, \ldots, \hat{\beta}_{n-1}$ yang memiliki MSE minimum. Adapun model kurva Lorenz versi Rohde yang terbentuk tersaji pada persamaan (9) dan sgini ratio yang dihasilkan lebih akurat dan presisi serta sesuai sebaran data.

\section{DAFTAR PUSTAKA}

Badan Pusat Statistik (BPS). 2016. Statistik Kesejahteraan Rakyat. Jakarta: BPS.

Basu, S.; Dasgupta, A. (1997). The Mean, Median, and Mode of Unimodal Distributions: A Characterization. Theory of Probability and Its Applications 41 (2), 210-223.

Castillo, E., Hadi, A.S., Sarabia, J.M., 1998. A method for estimating Lorenz curves. Communications in Statistics, Theory and Methods 27, 2037-2063. 
Chotikapanich, D., 1993. A comparison of alternative functional forms for the Lorenz curve. Economics Letters 41, 21-29.

Chotikapanich, D., Griffiths, B., Rao, D.S., 2007. Estimating and combining national income distributions using limited data. Journal of Business and Economic Statistics 25, 97-109.

Fajar, M., 2017. Pemodelan Parametrik Distribusi Pengeluaran Rumah Tangga Pertanian Provinsi Papua.DOI:10.13140/RG.2.2.13690.18882.Melalui:https://www.researchgate.net/publication/3 20099412_Pemodelan_Parametrik_Distribusi_Pengeluaran_Rumah_Tangga_Pertanian_Provins i_Papua.

Gastwirth, J.L., 1971. A general definition of the Lorenz curve. Econometrica 39,1037-1039.

Gastwirth, J., Glauberman, M., 1976. The interpolation of the Lorenz curve and Gini index from grouped data. Econometrica 44, 479-483.

Gupta, M.R., 1984. Functional form for estimating the Lorenz curve. Econometrica 52, 1313-1314.

Kakwani, N.C., Podder, N., 1973. On the estimation of Lorenz curves from grouped observations. International Economic Review 14, 278-292.

Lorenz, M. O., 1905. Methods of measuring the concentration of wealth. Publication of the American Statistical Association, Vol. 9, No. 70.9 (70), 209 - 219.

Sarabia, J.M., Prieto, F., Sarabia., 2010. Revisiting a functional form for the Lorenz curve. Economics Letters Vol. 107 (2), 249 - 252.

Tukey, J.W., 1977. Exploratory Data Analysis. Reading, Massachusetts: Addison-Wesley.

Ortega, P., Martín, A., Fernández, A., Ladoux, M., García, A., 1991. A new functional form for estimating Lorenz curves. Review of Income and Wealth 37, 447-452.

Rasche, R., Gaffney, J., Koo, A.Y.C., Obst, N., 1980. Functional forms for estimating the Lorenz curve. Econometrica 48, 1061-1062.

Rohde, N., 2009. An alternative functional form for estimating the Lorenz curve. Economics Letters $105,61-63$.

Rousseeuw, P.J., Bassett, G.W. Jr., 1990. The remedian: a robust averaging method for large data sets. Journal of the American Statistical Association 85 (409), 97-104

Sarabia, J.M., Castillo, E., Slottje, D.J., 1999. An ordered family of Lorenz curves. Journal of Econometrics 91, 43-60.

Weisberg, H.F., 1992. Central Tendency and Variability. Newbury Park Calif: Sage University Paper Series on Quantitative Applications in the Social Sciences.

Xia, D.F., Xu, S.L., Qi, F., 1999. A proof of the arithmetic mean-geometric mean-harmonic mean inequalities. RGMIA Research Report Collection Vol. 2 (1). 